Taken together with observations by other speakers, including Prof. K. Bloch, Prof. W. Bartley and Dr. M. G. Macfarlane, Prof. Gurd's and Dr. Green's findings suggest one possible aspect of the 'essential' nature of particular fatty acids. Thoso acids are prominent in the lipids of the main energy-yielding apparatus of the bacterial, plant or animal cell; perhaps the non-polar regions of certain vital sections of the protein skeleton of this apparatus require specific structures in the hydrophobic 'tails' of the lipids which must be present for full enzymatic activity to be displayed.

\section{F. H. Sloane-Stanley}

\title{
CHARACTERIZATION AND USES OF HUMAN DIPLOID CELL STRAINS
}

\begin{abstract}
A SYMPOSIUM on "The Characterization and Uses of Human Diploid Cell Strains (HDCS)", sponsored by the Permanent Section on Microbjological Standardization of the International Association of Microbiological Societies, was held in Opatija, Yugoslavia, during Septembor 24-26. Ninety-six delegates from 18 countries attended. The sessions covered the following topics: (1) The management of human diploid cell strains. (2) Biochemical, cytogenetic and immunological studies on human diploid cells. (3) Virus spectrum of human diploid cells. (4) Production of human virus vaccines in human diploid cell strains. (5) Results of clinical trials on the use of vaccines prepared in human diploid cell strains.

Many laboratories receiving the human diploid cell strains reported their success in propagating the cells and attributed most of their early failures in handling these strains to variations in media constituents. The cells showed the classic normal human diploid karyotype until approximately tho 40 th cell generation.

It was reported that, at least for some loci, cultured diploid cells carry and express the genes of their donor. The human diploid cell strains retain the donor's chromosomal complement; they also maintain biochemical and immunological properties of the donor cells. In a sense these observations are complementary, for they indicate at two structural levels an apparont genetic resemblance between the cultured cells and the somatic tissues of the host.
\end{abstract}

The numerous attempts to isolate latent viruses from these cells have been unsuccessful. Dangers from extraneous oncogenic viruses, inherent in the use of primary explants of animal tissue, are largely circumvented in the opinion of many workers when human diploid cell strains are used for vaccine production.

Investigations on the virus spectrum of human diploid cell strains indicated their susceptibility to many viruses. These strains were thought to be particularly valuable in work with the rhinoviruses which cannot generally be devected in other cell substrates. Since different human diploid cell strains vary in their sensitivity to rhinoviruses, it was felt important to use the most sensitive strains.

Both live attenuated and killed vaceines for parenteral inoculation or oral administration have been made in human diploid cell strains from poliovirus, rhinovirus, adenovirus, varicella, measles, vaccinia and rabies. Following adaptation to human diploid cell strains, all viruses investigated were said to give yields equal to those in other cell systems. Investigations with poliovirus showed that they retained their genetic markers when propagated in human diploid cell strains.

It was urged that all laboratories using human diploid cell strains for vaccine production limit themselves to a fow standardized cell strains, since the use of a wellcharacterized tissue culture system is as logical and necessary as the use of a well-charactorized virus to be propagated in this system.

Clinical investigations on a number of virus vaccines are in progress. It was reported that an oral poliomyelitis vaccine produced in human diploid cell strains has already been successfully tested in a large-scale fiold trial and that no untoward reactions have been noted in 7,000 subjects who have received vaccine during the past two years. It was also reported that such vaccines proliferated in the gastro-intestinal tract and elicited an antibody response.

On the basis of the investigations suggesting the feasibility of large-scale production of virus vaccines in human diploid cells strains, a sub-committee of the conference drafted "Minimum Requirements for Human Diploid Cell Strains to be Used in Vaccine Preparation". These requirements were presented to the symposium participants and adopted at a plenary session.

LigONARD HAYFLICK

Frank T. Perkins

Robert E. STEVENSON

\section{SCIENTIFIC RESEARCH IN NEW ZEALAND}

$\mathrm{T}$ HE report of the Department of Scientific and Industrial Research, Now Zealand, for the year ended March 31, 1963*, includes the Minister's statement, the report of the Council, the longer report of the Secretary, to which are attached brief reports from tho various Divisions, the Incorporated Research Associations, and on granted-aid research in the Cawthron Institute, Lincoln College, Massey University College of Manawatu, and the Industrial Development Department, University of Canterbury. The fifth annual report of the Ross Dependency Research Committee is appended, to which, as to the Divisional reports, a list of publications is attached. The Council in its report reiterates the view that a much more comprehensive review of research is needed than was

* New Zealand. Report of the Department of Scientific and Industrial Research for the year ended 31 March, 1963. Pp. 87. (H. 34.) (Wellington: Government Printer, 1963.) $3 s$. given by the Royal Commission on State Services, but supports the proposal to replace the present Council, which is advisory only to the Department of Scientific and Industrial Research, with a National Research Council responsible for advising the Government on all aspects of research in Government Departments. The new Council should be advised by a number of export committees, but the Department of Scientific and Industrial Research must retain many of the existing expert committees. Research and development expenditure in New Zea. land in 1961-62 was still only 0.3 per cent of the gross national product or $£ 1.9$ per head of the population, the Department's gross expenditure of $£ 2 \cdot 19$ million being 0.163 per cent of the gross national product. Staff at March 31, 1963, numbered 1,229, including 455 scientific officers, compared with 1,170 and 442 , respectively, the previous year. An increase of 60 in the staff has been 